\title{
An Empirical Research on Inter-firm Capital Relationship in Yokokai Using IDE Spatial Model
}

\author{
Takao Ito*, Tsutomu Ito, Katsuhiko Takahashi \\ Graduate School of Engineering, Hiroshima University, Higashi-Hiroshima, 739-8527 Japan \\ Makoto Sakamoto, Satoshi Ikeda \\ Dept. of Computer Science and Systems Engineering, University of Miyazaki, 889-2192 Japan \\ Rajiv Mehta \\ School of Management, New Jersey Institute of Technology, 07102-1982 U.S.A
}

\begin{abstract}
This paper introduces recent fundamental modifications to the Japanese alliance system known as the keiretsu, and analyses how these changes have affected corporate performance. More specially, the performance of Japanese auto manufacturers, such as Toyota, Nissan and others, has significantly improved due to sophisticated production system technologies, highly productive workers, and recurring transaction relationships with their network family partners. After economic bubble of the 1990s, the strong ties between automobile makers and their supplier partners experienced significant changes, which are known as "keiretsu loosening". Consequently, what is the status quo of automotive keiretsus? Does cross-shareholding, which is one specific form of capital relationship in keiretsu, still contribute to improving corporate performance? To answer these questions, this research reports the results of a study that collected data on cross-shareholdings to shed light on the relationship between inter-firm capital relationship and corporate performance. The findings of this empirical investigation reveal that: (1) Keiretsu is a flexible, highly adaptive organizational form; its scale changes in response to economic situations; (2) Capital relationships still remain a significant determinant of increasing profits for keiretsu partners even after the bubble burst in the 1990s.
\end{abstract}

Keywords: Influence, Degree, Effective Size, the IDE model, keiretsu loosening.

\section{Introduction}

Japanese automobile manufacturers still show signs of performing at a significantly higher level than their global counterparts. This could possibly be due to the sophisticated technologies deployed for their production systems, highly productive employees, and continuous transaction relationships with other member-partners in the keiretsu network. Possibly, one explanatory factor contributing to their success could be due to their unique organization forms-the keiretsu-which provides a strong platform to forge strategic alliances with their parts suppliers, as well as collaboration in research and development with other automobile makers. In the aftermath of the 1990s economic bubble, the strong linkages between auto manufacturers and their parts suppliers in the keiretsu network underwent a significant phenomenon: "keiretsu loosening".

Thus, it is necessary to determine the current status quo of keiretsus. More specifically, does cross shareholding, which is a specific capital relationship in keiretsu, is associated with higher levels of corporate performance? To find answers to this and related questions, the purpose of this research-manuscript-based on a review the extant literature on keiretsu-is to propose a new paradigm known as the IDE spatial model, which sheds light on the interrelationship between capital crossshareholding and corporate performance. 
This manuscript is organized as follows: Section 2 reviews the relevant literature associated with keiretsu networks. Section 3 describes the data collection process and the new network model. Based upon the findings, the managerial implications are discussed in section 4. In section 5, the study limitations are identified and avenues of future research are proffered.

\section{Background}

As a well-known network organization in Japan, keiretsus, in general, can be of two forms: horizontal and vertical. Horizontal keiretsu consist of zaibatsu, while vertical keiretsu comprise constellation members of a manufacturing group, such as like Toyota's Kyohokai and Nissan's Nishokai. Most manufacturing firms developed with financial support from zaibatsus. However, Toyota exemplifies a unique keiretsu that developed without financial support from any zaibatsu. As a special case, this paper will focus on Mazda because of the global success it has sustained.

Ties among keiretsu partners are complex. Basically ties can be of several forms that include equity ties, personal ties, transactional ties and work-flow ties. This paper examines one derivative of equity data called cross shareholding to reveal ties and corporate performance. Having become a successful model of inter-firm cooperation, keiretsu involves any type of relationship between one or more companies attempting to pursue individual and joint corporate and market related goals that each firm alone could not easily attain. It is based on the notion that it is difficult for a firm to "go it alone" and excel in performing all business functions. Keiretsu are formidable organizational forms owing to their global reach and lower investment costs. And cooperation forms the "heart" of keiretsu alliances.

Consequently, it is crucial to clarify the essential principles of the rational inter-firm alliances not only based on theoretical research, but also based on quantitative approaches.

Although many quantitative methods have been developed, an effective mathematical tool-graph theorycan be used to study keiretsu. As a network organization, the interrelationships among member partners in keiretsu should be calculated from the viewpoint of centrality, density, effective size, and influence, among other factors. To find new approaches, many studies have been published on keiretsu. In 2004, Ito collected the transactional data and found that strong relationship between corporate centrality and their performance in Toyota keiretsu [1]. Fukuoka et al. calculated correlation ratio between transaction and cross shareholdings data and found a positive relationship between the correlation ratio and corporate performance after comparing Nissan and Toyota [2]. What's more, Ito et al. discovered rational relationship between network indices such as centrality and capacity and corporate performance in Mazda's Yokokai [3, 4]. And more recently, Tagawa et al. uncovered the relationship between organizational structure and corporate performance, such as sales and profits in Mazda's Yokokai [5]. All these investigations support the theory that mutual assistance and access to stable financing are equally important in leveraging the performance of automotive manufacturing firm.

After the economic bubble collapse of the 1990s, the strong ties between automobile manufacturers and their suppliers in keiretsu experienced a significant change known as "keiretsu loosening". McGulre and Dow indicate that the four characteristics which underscore the evolution of keiretsu ties are: (1) diminished bank debt; (2) reduced cross-holdings; (3) reduced buyersupplier ties (vertical keiretsu); and (4) diminished inter-firm exchanges of board and personnel [6]. Thus, the literature review reveals that many scholars have found results congruent with those found by McGulre and Dow.

Because of the importance of keiretsu, the following research questions are investigated: What is the status quo of present-day keiretsu? Is cross shareholding, which is a specific capital relationship in keiretsu, still a statistically significant predictor of corporate performance? To our best knowledge, no research provides answers to these questions. Thus, this research makes a contribution to the literature, by bridging the gap in the knowledge on this aspect related to keiretsu.

\section{Data Collection and Variables Selection}

To shed light on these issues and to examine the network relationship between cross shareholdings and corporate performance, data were collected from Mazda's keiretsu, Yokokai, which comprises three suborganizations: Nishi-Nihon Yokokai, Kanto Yokokai and Kansai Yokokai. 


\subsection{Data Collection}

Data were collected for 1985, 1993, 1997 and 2004 fiscal years to establish the status quo of keiretsu and ascertain changes in its structure in the aftermath of the bubble economy. The detailed information of Yokokai is shown in Table 1.

Table 1 Yokokai Network Data with Singletons

\begin{tabular}{|c|c|c|c|c|}
\hline & Suppliers & $\begin{array}{c}\text { Banks and financial } \\
\text { institutions }\end{array}$ & $\begin{array}{c}\text { Car } \\
\text { makers }\end{array}$ & $\begin{array}{c}\text { Total } \\
\text { Number }\end{array}$ \\
\hline 1985 & 178 & 46 & 11 & 235 \\
\hline 1993 & 188 & 48 & 11 & 240 \\
\hline 1997 & 190 & 53 & 11 & 254 \\
\hline 2004 & 177 & 36 & 11 & 224 \\
\hline
\end{tabular}

Table 1 includes data on singletons, which refers to a partner firm in the keiretsu that has no relationship with other member firms. Singletons were removed from the data-set because singletons have no impact on the calculation of network indexes. The revised data is shown in Table 2.

Table 2 Yokokai Network Data without singletons

\begin{tabular}{|c|c|c|c|c|}
\hline & Suppliers & $\begin{array}{c}\text { Banks and financial } \\
\text { institutions }\end{array}$ & $\begin{array}{c}\text { Car } \\
\text { makers }\end{array}$ & $\begin{array}{c}\text { Total } \\
\text { Number }\end{array}$ \\
\hline 1985 & 72 & 19 & 9 & 100 \\
\hline 1993 & 75 & 29 & 11 & 115 \\
\hline 1997 & 85 & 27 & 10 & 122 \\
\hline 2004 & 57 & 35 & 9 & 101 \\
\hline
\end{tabular}

Capital relationship in Yokokai, which was also collected, refers to the amount of stock one company buys in network partners. Network member firm invests in each result in a phenomenon known as cross shareholding. Table 3 shows the cross shareholding data in Yokokai.

Table 3Yokokai Network Matrix Data in 1985

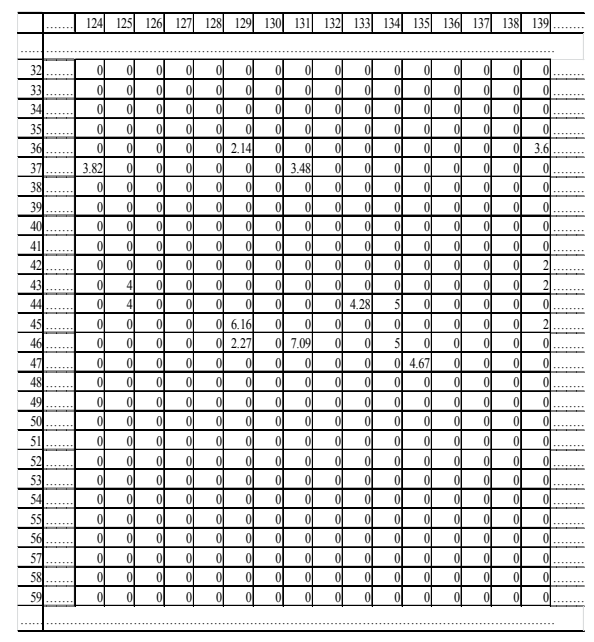

For instance, No. 47 of Mazda buys 4.67 percent stocks from No. 135 of Nittan Valve Company. As such, the cell between Mazda and Nittan Valve Company is 4.67 percent. In other words, Nittan Valve Company accepts Mazda's invest and the amount is 4.67 of its total capital. All of the inter-firm capital relationship in 1985, 1993, 1997, and 2004 can be illustrated as Fig. 1.

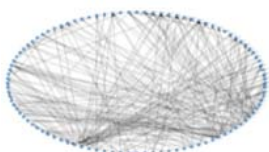

1985

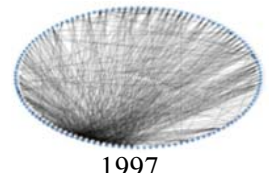

1997

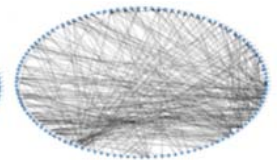

1993

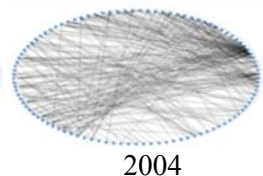

2004
Fig. 1. Capital Networks in Yokokai.

\subsection{Research Hypotheses}

As previously noted, many structural indices of network analysis have been developed. This study selected degree, influence and effective size of the firms included in Yokokai to analyze the relationship between those indices and corporate performance.

Degree is an index of a firm's potential communication activity. In a network, cross shareholding degree includes two categories: in-degree and out-degree. This is because cross shareholding networks are considered to be asymmetric organizations. In-degree refers to a firm accept investment from other member firms, whereas out-degree reflects a firm that only buy stocks from other firms within the network. Degree is calculated as below [7].

$$
C_{D}\left(p_{k}\right)=\sum_{i=1}^{n} a\left(p_{i}, p_{k}\right)
$$

where

$\mathrm{a}\left(\mathrm{p}_{\mathrm{i}}, \mathrm{p}_{\mathrm{k}}\right)=1$; if and only if $\mathrm{p}_{\mathrm{i}}$ and $\mathrm{p}_{\mathrm{k}}$ are connected by a line; $\mathrm{a}(\mathrm{pi}, \mathrm{pk})=0$; otherwise

Percentage data of inter-firm's transactions were collected from Yokokai. In a transactional network, high value of degree is positively associated with its corporate performance such as sales and profit [8, 9]. Based upon this prior work, the following hypothesis is postulated:

H1: Out-degree will be positively associated with its profit, and in-degree will be negatively associated with its profit.

Influence reflects the power to influence or have an impact on other member firms directly and indirectly in a network. Consequently, influence is being divided into 
two parts: direct influence and indirect influence. Suppose that $\mathrm{A}$ is the matrix of the direct network, and $\mathrm{A}^{\mathrm{n}}$ means the indirect influence from one firm to another firm by $\mathrm{n}$ steps. Then influence is calculated as follows.

$$
\begin{aligned}
& T=A+R=A+A^{2}+A^{3}+\cdots+A^{n} \\
& =A(I-A)^{-1}
\end{aligned}
$$

where
T: Total influence;
A: direct influence;

$\mathrm{R}$ : indirect influence; I: Identity matrix.

In an asymmetric network, cross shareholding influence includes two categories: influence and affectedness. Influence refers to a firm have strong impact on other member firms, whereas affectedness reflects a firm that only influenced by other firms within the network. In same network, influence has a strong impact on corporate performance [9]. Consequently, the following hypothesis proffered:

$\mathrm{H} 2$ : Influence will be positively associated with its performance and affectedness\#\# will be negatively associated with its profit.

Effective size of the network refer to the number of alters that ego has, minus the average number of ties that each alter has to other alters. It can be calculated as follows [10].

$$
E S_{i}=\sum_{j}\left[1-\sum_{q} p_{i q} m_{j q}\right] ; q \neq i, j
$$

where

$\mathrm{m}_{\mathrm{jq}}$ : i's interaction with $\mathrm{q}$ divided by j's strongest relationship with node

$\mathrm{p}_{\mathrm{iq}}$ : proportion of i's energy invested in relationship with $\mathrm{q}$

A recent study investigated the relationship between firm network position and corporate venture capital investment [11]. In another study, Sakamoto et al. reported effective size is one of the key determinants associated with corporate performance in transaction network [12]. Accordingly, the following hypothesis is posited:

H3: Effective-size will be positively associated with its profit.

A three dimension is composed of a set of network indexes: degree, effective size, and influence. The position of each firms located in the three dimension will be considered as one factors of its performance. Euclidean distance in the three dimension space is calculated as follows.

$$
D=\sqrt{\left(x_{i}-x_{k}\right)^{2}+\left(y_{i}-y_{k}\right)^{2}+\left(z_{i}-z_{k}\right)^{2}}
$$

where

$\left(\mathrm{x}_{\mathrm{i}}, \mathrm{y}_{\mathrm{i}}, \mathrm{z}_{\mathrm{i}}\right)$ : position of each firm i's

$\left(\mathrm{x}_{\mathrm{k}}, \mathrm{y}_{\mathrm{k}}, \mathrm{z}_{\mathrm{k}}\right)$ : position of Mazda's

Euclidean distance is the measure to calculate the distance among each firm. Basically the distance between each firm to Mazda should be considered that the longer distance, the less performance. Accordingly, the following hypothesis is posited:

H4: Distance between each firm and Mazda will be negatively associated with its profit.

\section{Results}

Degree, influence and effective size are calculated in this paper. In order to calculate the relationship between network indexes and its corporate performance, the data of corporate performance such as sales and profits are collected.

The results reveal that all of the indices are statistically significant except affectedness. Table 4 shows descriptive statistics for all significant variables and parameters in the regression model. From 1985 to 2004, only two variables: influence and out-degree are significant.

Table 4. Regression Results for Study Variables.

\begin{tabular}{l|r|r|r|r}
\hline & \multicolumn{4}{|c}{ Models } \\
\cline { 2 - 5 } & \multicolumn{1}{|c}{2004} & \multicolumn{1}{c}{1997} & \multicolumn{1}{c}{1993} & \multicolumn{1}{c}{1985} \\
\hline Influence & & & & \\
Partial regression coefficient & 7.9407 & 110.2012 & 23.898 & 12.3072 \\
Standard coefficient & 7.9407 & 110.2012 & 23.898 & 12.3072 \\
t value & 2.6339 & 13.1839 & 4.3258 & 3.0193 \\
Probability & 0.0104 & 0 & 0 & 0.0034 \\
Correlation coefficient & 0.7631 & 0.5027 & 0.4357 & 0.3862 \\
Partial correlation coefficient & 0.3023 & 0.864 & 0.3874 & 0.3146 \\
\hline Out-degree & & & & \\
Partial regression coefficient & -7.1798 & -109.701 & -23.5139 & -12.3795 \\
Standard coefficient & -7.1798 & -109.701 & -23.5139 & -12.3795 \\
t value & -2.3815 & -13.124 & -4.2578 & -3.0666 \\
Probability & 0.02 & 0 & 0 & 0.0029 \\
Correlation coefficient & 0.7584 & 0.4976 & 0.4306 & 0.3767 \\
Partial correlation coefficient & -0.2756 & -0.863 & -0.3822 & -0.319 \\
\hline Intercept & & & & \\
Partial regression coefficient & 0.0398 & 0.1294 & 0.4882 & 0.0418 \\
Standard coefficient & 0 & 0 & 0 & 0 \\
t value & 0.5053 & 2.1565 & 4.1739 & 0.2925 \\
Probability & 0.615 & 0.0351 & 0.0001 & 0.7706 \\
\hline In-degree & & & & \\
Partial regression coefficient & 1.0393 & -0.1029 & -0.1888 & -0.2622 \\
Standard coefficient & 1.0393 & -0.1029 & -0.1888 & -0.2622 \\
t value & 0.7636 & -1.4928 & -2.3124 & -3.3958 \\
Probability & 0.4478 & 0.141 & 0.0227 & 0.0011 \\
Correlation coefficient & -0.2005 & -0.2413 & -0.3194 & -0.3517 \\
Partial correlation coefficient & 0.0936 & -0.194 & -0.2191 & -0.3493 \\
\hline Effective-size & & & & \\
Partial regression coefficient & 0.0298 & 0.1347 & 0.1252 & 0.5654 \\
Standard coefficient & 0.0298 & 0.1347 & 0.1252 & 0.5654 \\
t value & 0.2848 & 1.2797 & 1.128 & 4.7651 \\
Probability & 0.7767 & 0.2058 & 0.2619 & 0 \\
Correlation coefficient & 0.3838 & 0.5468 & 0.4327 & 0.6242 \\
Partial correlation coefficient & 0.035 & 0.1671 & 0.1094 & 0.4635 \\
\hline Coefficient of determination & 0.61402 & 0.80933 & 0.35482 & 0.5351 \\
\hline Multiple correlation coefficient & 0.7836 & 0.89963 & 0.59567 & 0.7315 \\
\hline F value & 54.88311 & 125.2159 & 14.43634 & 23.88286 \\
\hline Degree of freedom & 2,69 & 2,59 & 4,105 & 4,83 \\
\hline & & & & \\
\hline
\end{tabular}




\begin{tabular}{l|r|r|r|r}
\hline AIC & 141.79 & 79.2 & 273.96 & 192.33 \\
\hline DW ratio & 1.2225 & 2.0963 & 2.2046 & 1.3565 \\
\hline Data number & 72 & 62 & 110 & 88 \\
\hline
\end{tabular}

The three dimension model in 1985 is illustrated as Fig. 2.

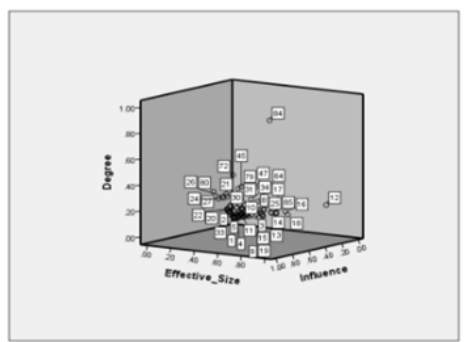

Fig. 2 Position of each firm in three-dimension in 1985

\section{Analysis and Discussion}

The implications of our results can be considered as follows.

\subsection{Out-degree and In-degree}

In capital network, out-degree refers to the amount of investment in other partner companies, and in-degree refers to the amount of investment accepted from other companies. From 1985 to 2004, the partial correlation coefficient of out-degree is $-0.319,-0.3822,-0.863$, and -0.2756 , respectively. In-degree is significant only in 1985 and 1993, they are -0.3493 and -0.2191 .

All of the out-degree is significant, but the relationship is the inverse. This means that higher investments are associated with less profit. According to the findings reported by Sakamoto et al., H1 is supported in transactional network, but in capital network, out-degree is negatively associated with profit. However, in McGuire and Dow's study, one of the conclusions is incongruent because out-degree is negative even before the bubble economy collapsed. Much more quantitative research should be done to find support for their arguments. As interesting finding is that value in 1997 is very high. And the value returned to normal levels in 4 years after its adjustment. The values of in-degree in 1985 and 1993 are significant, but in 1997 and 2004 they are not significant. The bubble economy occurred at the beginning of 1990. Evidently, keiretsu began to adjust their structure after bubble economy collapsed. Therefore, it is apparent that the dramatic loosening of keiretsu occurred in Yokokai. Out-degree is a reflex of this change. Upon close investigation, the membership of Yokokai manifests a significant change. Most firms with weak competition disappeared and some strong firms such as Toyota's suppliers become new members in Yokokai. Thus, based upon the analysis described above, there is partial statistical support for H1.

\subsection{Influence}

Influence is one kind of power to affect persons or events without any direct or discernible effort. Influence reflects the power to influence or have an impact on other member firms directly and indirectly in a network. Influence depends on network depth. The depth of Yokokai is 3, which suggests that depth still has impact on its influence. From 1985 to 2004, the partial correlation coefficient of influence is $0.3146,0.3874$, 0.864 , and 0.3023 respectively.

This result shows that all partial correlation coefficients are positive and significant. The value in 1997 is extra high. And the value returned to normal by 7 years after its adjustment. This coincides with the out-degree findings. Invest or buy stock from other companies is an effective way to maintain its influence in network suggesting that higher influence is associated with increased profits. Therefore, there is strong support for $\mathrm{H} 2$.

\subsection{Effective Size}

Effective size is analogous to the ego's network. The firm has strong connected neighbors if the value of effective size is high. Basically, strong connected neighbors can be considered as good condition to invest because all of the firms invest in each other within the keiretsu. The value of effective size $(0.4635)$ only in 1985 is statistically significant. Therefore, there is support for $\mathrm{H} 3$ for the period before the collapse of the bubble economy. Evidently, keiretsu already made a major policy shift by breaking with the so-called "convoy system" of alliance networks.

\subsection{Euclidean distance}

There is statistical support for H4 only in 1993 and 1997. The partial correlation coefficient is -0.2097 and 0.4797 respectively. In 1985 and 2004, partial correlation coefficients are positive, and the probability in 2004 is significant, but insignificant in 1985. This readily reveals that the same characteristics of changing of degree, effective size and influence occurred in 2004. Consequently the reason of keiretsu loosening in 
Yokokai is not the bubble economy of the 1990s, but can be ascribed to the rational capital relationship of Yokokai as maintained in 1993 and 1997. The distance between each parts supplies and Mazda is not an important determinant of profit in 1985 and 2004, but the distance is a crucial factor of profit in 1993 and 1997. Accordingly the rational inter-firm relationship is adjusted frequent according to the change of economic situation, and its parts purchasing policy of each supplier. After bubble economy, the member of Yokokai has been changed because many competitive firms in Kyohokai: the parts supplies in keiretsu of Toyota began to deal with Mazda. Anyway, it is easy to indicate that inter-firm relationship is adjusted based upon the purchasing strategy rather than the course of events.

\section{Conclusion and future research avenues}

This paper proposed four hypotheses between profit and network indexes including degree, influence and effective size, and Euclidean distance. The linkage between profit and influence is supported, whereas there is partial support for the association between profit and degree. The linkage between profit and effective size holds only before bubble economy collapsed. On analyzing the background of the membership change in Yokokai, the results show that rational inter-firm relationships in keiretsu are still associated with corporate performance. This suggests that keiretsu loosening resulted in performance improvement as cross share-holdings were still maintained, which also coincides with the result obtained in the Euclidean analysis. Some factors, such as affectedness and effective size are not statistically significant. Thus, additional factors should be identified as potential determinants of profit. Data were drawn from Mazda's Yokokai to test the hypotheses. Thus, to test the validity of these research findings, additional studies should replicate this research by drawing data from other keiretsus, such as Toyota's Kyohokai and Nissan's Nishokai.

Acknowledgment: This work was supported by JSPS KAKENHI Grant Number 24510217.

\section{References}

1. Ito T. (2004) Quantitative analysis of the firm's relationship in the Keiretsu of Toyota group, Proceedings of the 2004 Information Resources Management Association, International Conference, Innovations Through Information Technology, pp.1078-1079, May 23-26, 2004, New Orleans, USA.

2. Fukuoka S., Ito T., Passerini K., and Sakamoto M. (2006) An Analysis between Transaction and Cross Shareholdings in the Keiretsu of Nissan, Proceedings of the 6th International Business Information Management Association, International Conference, Managing Information in Digital Economy, pp. 163-169, June19-21, 2006, Bonn, Germany.

3. Ito T., Takida R., Matsuno S., Mehta R., Ishida Y., and Sakamoto M. (2011) An analysis of a firm's capacity in Mazda's Keiretsu, Artificial Life and Robotics, Volume 16, Number 2, pp. 248-252, Springer Japan, 2011.

4. Ito T., Niki E., Takida R., Mehta R., Passerini K., and Sakamoto M. (2011) Transactions and cross shareholdings in Mazda's Keiretsu: a centrality analysis, Artificial Life and Robotics, Volume 16, Number 3, pp.297-300, Springer Japan, 2011.

5. Tagawa S., Ito T., Mehta R., Passerini K., Voges K., and Sakamoto M. (2012) Organizational structure of Mazda's Keiretsu: A graph theoretic analysis, Artificial Life and Robotics, Volume 16, Number 4, pp.455-459, Springer Japan, 2012.

6. McGulre J, Dow S., (2009) Japanese keiretsu: Past, present, future, http://download.springer.com/static/ pdf/983/art\%253A10.1007\%252Fs10490-008-91045.pdf?auth66=1399794791_ce53db11bd93d8098b0304e1 6daae06f\&ext=.pdf, retrieved May 9, 2014

7. Nieminen J. (1974), On centrality in a graph , Scandinavian Journal of Psychology 15, pp. 322-336.

8. T. Ito and C. Medlin, (2011) Network Governance: Network Closeness and Firm Performance, Globalisation, Governance and Ethics: New Managerial and Economic Insights, J. M. Aurifeille, C. J. Medlin, C. Tisdell, J. G. Lafuente, and J. G. Aluja (Eds.), Chapter 10, pp.125142, Nova Science.

9. T. Ito, C. Medlin, K. Passerini, and M. Sakamoto, (2009) Influence Trust and Trade in the Keiretsu of Toyota: A Centrality Analysis, Trust, Globalisation and Market Expansion, J. M. Aurifeille, C. J. Medlin, \& C. Tisdell (Eds.), Chapter 8, pp.101-118, Nova Science.

10. Borgatti S. P., (1997) Structural Holes: Unpacking Burt's Redundancy Measures, http://www.analytictech.com/ connections/v20(1)/holes.htm, retrieved Nov. 25, 2013

11. Erik Noyes, Candy Brush, Ken Hatten, and Laurel SmithDoerr, (2014) Firm network position and corporate venture capital investment, Journal of small business management, 2014 52(4).

12. Makoto Sakamoto, Satoshi Ikeda, Takao Ito, Rajiv Mehta, Seigo Matsuno, Shinya Tagawa, and Victor D. Berdonosov, (2014) An Empirical Examination of Interfirm Capital Relationships in Mazda's Yokokai using the IDE Spatial Model, Journal of Robotics, networking and Artificial Life, Volume 1, Issue 2, pp. 150-154, Atlantis Press 